\title{
LESSON 25
}

\section{Postcodes}

Practise typing postcodes

PAPER: A5 $(210 \times 148 \mathrm{~mm})$.

MARGINS:

Left, Pica 10; Elite, 12;

Right, moved out of the way.

Turn up 7 single-line spaces. Set a tab in the middle of the page to locate the starting point of the second address. Keep the sheet for reference.

Letter 6

PAPER: A4.

MARGINS: Suitable.

TARGET TIME: 12 minutes.

Turn up 13 single lines before starting to allow for the printed heading.

Using your framework, space the letter out correctly.

Ltd. (Limited)

Co. (Company)

Suitable Margins

In Elite type -

$\begin{array}{ccc}\begin{array}{c}\text { WORDS } \\ \text { under 150 }\end{array} & \begin{array}{c}\text { PAPER } \\ \text { A5 }\end{array} & \begin{array}{c}\text { MARGINS } \\ \text { never less } \\ \text { than 12-60 }\end{array} \\ 150-250 & \text { A4 } & 24-76 \\ 250-350 & \text { A4 } & 18-82 \\ 350-400 & \text { A4 } & 12-188\end{array}$

In Pica type -

$\begin{array}{ccc}\begin{array}{c}\text { WORDS } \\ \text { under 120 }\end{array} & \begin{array}{c}\text { PAPER } \\ \text { A5 }\end{array} & \begin{array}{c}\text { MARGINS } \\ \text { never less } \\ \text { than 5-53 }\end{array} \\ 120-200 & \text { A4 } & 20-62 \\ 200-250 & \text { A4 } & 15-67 \\ 250-350 & \text { A4 } & 10-72\end{array}$

Note: left margin must not be narrower than right margin.

UNIT 7

The postcode is typed on both letter and envelope. It is placed either directly under the last line of the address or not more than 6 spaces or less than 2 spaces to the right of the last line of the address on the letter. Postcodes on envelopes must always be typed under the last line of the address. Use a full stop after the last word of the address but do not punctuate the postcode, which is typed in two parts with a space between the parts. The Post Office Guide gives full information.

Miss J. Tierney, 16 Cranley Drive, Albrighton.

Salop.

AL3 6CX

Ref. $\mathrm{AD} / \mathrm{NS}$

To-day's date

The Manager,

Family Value Stores Ltd., The Arcade, Dudley. DU6 7AR

Dear Sir,

We think you will be interested in the additions to our frozen food range. Samples of all our new products will be delivered by our van driver when he calls with your next delivery. Our Area Representative, Mr. Tom Mason, will be calling on you soon to explain our advertising plans and to give you details of a generous discount to be allowed on purchases during the introductory offer.

The new products are the result of months of careful researck both in this country and in America, and we feel that they will rapidly expand the frozen food market. We confidently submit them for your scrutiny.

The enclosed literature will provide you with the background information to the new products.

Yours faithfully,

A. Davies

Advertising Manager

Enc.

LESSON 25 